\title{
Food safety: current situation, unaddressed issues and the emerging priorities M. Elmi
}

\begin{abstract}
SUMMARY This paper reviews the topic of food safety with reference to the Eastern Mediterranean Region. The differing views of food safety and the current situation with regard to ensuring food safety are presented. Also discussed are some of the unaddressed issues and challenges related to food safety. The new conditions that have arisen in the modern world which have facilitated the emergence of pathogens are presented, such as changes in animal husbandry, changes in international trade and travel, lifestyle and consumer changes. The urgent need for action in order to reduce the risk of microbiological and chemical foodborne diseases is emphasized. The food chain starts from farm and ends at fork; controlling this complex process requires an integrated approach and a responsible authority to oversee it in order to protect and promote food safety.
\end{abstract}

\section{Introduction}

Food is a means to sustain and enjoy life but it is also a vehicle and a medium for transmitting hazards and causing disease and death. Foodborne diseases are a growing public health problem in both developed and developing countries today. The term "safe food" represents different ideals to different audiences. Views and descriptions of safe food held by consumers, academicians, industry and special interest groups differ and are diverse. Thus almost any single definition of food safety will be overly simplistic [1].

For consumers, the descriptions of safe food are generally quite practical and simple. Consumers of course come in all sorts; they differ in age, sex, culture, life experience, health, knowledge, nutritional needs, family status, purchasing power, occupation, education and access to the media. Thus their ideas of safe food will vary. For example, some may regard safe food as food that does not make a person sick. Others may describe safe food as food that is within its shelf life and has been stored or distributed at the proper temperature. Some consumers may define safe food as food that is not "contaminated".

The colloquium on food safety for the American Academy of Microbiology has described safe food as the following: Safe food, if properly handled at all steps of production, processing, distribution, from retail and food service business through consumption, is reliably unlikely to cause illness or injury [2]. The food industry defines food safety by its specification for raw materials and finished products. These specifications define the acceptable limits for chemical hazards such as hormones and pesticides, physical hazards such as metal fragments, and microbiological hazards such as Salmonella and Listeria. Food safety of course goes beyond food production and sale to the consumers themselves

${ }^{1}$ Regional Adviser, Food and Chemical Safety, WHO Regional Office for the Eastern Mediterranean, Cairo, Egypt.

المحلة الصحية لشرق المتو سط، منظمة الصحة العالمية، البحلد العاشر، العدد ج، ع • + 
and their own handling and consumption of food.

The World Health Organization (WHO) and Food and Agriculture Organization (FAO) define food safety as food that is free from all hazards, whether chronic or acute, that may make food injurious to the health of the consumer [3].

\section{Current situation in the Eastern Mediterranean Region}

Food safety in Eastern Mediterranean Region of the World Health Organization varies considerably throughout the Region. In recent years, an increasing number of countries have moved to improve, update and strengthen their systems and infrastructure for food safety and have adopted an approach based on risk management. The United Arab Emirates and Jordan have developed modern food control systems based on risk management to monitor and control the safety of domestically produced and imported food. Oman and Tunisia have developed a national strategy for food control. Lebanon, Egypt, Pakistan, Sudan, Syrian Arab Republic and Morocco have drafted new food legislation. Egypt and Sudan harmonized food standards with Codex. Saudi Arabia, Jordan and the Islamic Republic of Iran have established a food and drug authority. Members of the Gulf Cooperation Council (Bahrain, Kuwait, Oman, Qatar, Saudi Arabia and the United Arab Emirates) have developed a common food import policy which allows for shared inspection policy and standards. The inspection systems for domestic and imported food of the United Arab Emirates make use of hand-held computers and customized software, which enhances access to information of on high-risk foods, accelerates clearing processes and improves performance of food safety. Some countries have well-functioning foodborne surveillance systems and reporting mechanisms, such as Jordan, Kuwait, Oman and Saudi Arabia. Given the strong reliance of the Region on food imports, ensuring the safety and quality of imported food is a recognized concern throughout the Region [4].

Many countries in the Region have embarked on unifying food safety activities from farm to fork, such as Jordan, Saudi Arabia and Bahrain. They have established or are establishing food and drug authorities which will cover food laws and regulations, food control management, foodborne disease surveillance and investigation systems, inspection services, recall and tracking systems, food monitoring laboratories, and information and education activities for the consumers themselves.

\section{Unaddressed issues and challenges}

Foodborne diseases are perceived by the majority of the people in developing countries as an unpleasant fact of daily life. Because most people regard diarrhoea as a transient inconvenience rather than a symptom of disease, the vast majority of diarrhoeal episodes do not result in a visit to a doctor [5].

Trends in global food production, processing, distribution and preparation present new challenges to food safety. Food grown in one country can now be transported and consumed halfway across the world. People demand a wider variety of foods than in the past, they want foods that are not in season and they often eat out of the home [6]. Children in schools and childcare facilities and the growing number of elderly persons in hospitals and nursing homes mean that food for many is prepared by a few and can therefore be the source of major foodborne disease outbreaks [7].

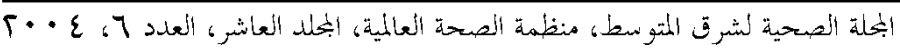


Greater life expectancy and increasing numbers of immunocompromised people mean a larger vulnerable population for whom unsafe food is often an even more serious threat $[8,9]$.

\section{Emerging priorities}

In the last two decades, new pathogens have been recognized as being transmitted through food, these are either newly described pathogens or newly associated with foodborne transmission; they include Salmonella enteridis, Campylobacter, verocytotoxin-producing Escherichia coli (VTEC), Listeria monocytogens, Noroviruses, Vibrio cholerae O1, V. parahaemolyticus, V. vulnificus, Yersinia enterocolitica, Cyclospora and prions. Most of these pathogens have an animal reservoir but they do not often cause illness in the infected animal (chickens and S. enteritidis, cattle and E. coli O157:H7, oysters and $V$. vulnificus and Norwalk viruses and Listeria monocytogenes) [10-12].

\section{New conditions facilitating the emergence of pathogens}

A number of factors can explain the emergence of new foodborne pathogens as well as the re-emergence of older, well known pathogens over the last 2 decades.

New animal feeding practices

Even before the exact cause of bovine spongiform encephalopathy (BSE) was known, the actual driving force of the epidemic was identified, namely cattle feeding practices. The establishment of BSE in its new bovine host and subsequent epidemic spread has been clearly linked to the use of meat and bone meal from cattle and other ruminants in the preparation of cattle feed $[5,8]$.
Changes in animal husbandry

Modern intensive animal husbandry practices, introduced to maximize production, seem to have led to the emergence and increased prevalence of Salmonella serovars and/or Camplyobacter in domestice animals, such as poultry, cattle, sheep and swine $[5,13,14]$.

\section{Increase in international trade}

International trade has three main consequences: i) the rapid transfer of microorganisms from one country to another, ii) the time between processing and consumption of food is increasing, leading to increased opportunity for contamination and time/temperature abuse of the products and hence the risk of foodborne illness, and iii) people are more likely to be exposed to a higher number of different strains/types of foodborne pathogens [5].

\section{Changes in the agronomic process}

The use of untreated sewage for irrigation and increased use of manure rather than chemical fertilizers contributes to the increased risk associated with the consumption of fresh fruits and vegetables. Countries where an important increase in consumption of such products has occurred in recent years have experienced increases in outbreaks of $E$. Coli and $C y$ clospora infection [15-19].

\section{Changes in food technology}

Advances in food technology on a global scale have enabled the food industry to supply a greater variety of foods, especially ready-to-eat foods. The increased use of refrigeration to prolong the shelf-life of food has contributed to the emergence of Listeria monocytogenes; this bacterium is adapted to survive at freezing temperature $[5,20]$. 
Increase in travel

Seven hundred and sixty million international arrivals were recorded worldwide in 2004 and this number is expected to increase to 937 million by 2010 [21]. Globalization of foodborne diseases results from such increased travel. Thus, a person can be exposed to a foodborne illness in one country and expose others to the infection in a location thousands of kilometres from the original source of infection. Depending on their destination, travellers are estimated to run a $20 \%$ to $50 \%$ risk of contracting foodborne diseases [22]. For example, $90 \%$ of salmonellosis in Sweden, $71 \%$ of typhoid fever cases in France and $61 \%$ of cholera cases in the United States of America have been attributed to international travel $[5,23]$.

\section{Changes in lifestyle and consumer demands}

Fifty years ago there were far fewer restaurants, and salad bars were virtually nonexistent. Today, however, both abound and eating out is commonplace. As a result, an increasing number of outbreaks of foodborne infection are associated with foods prepared outside the home. Hitherto unrecognized microbial hazards have emerged because of changes in food consumption, such the increasing consumption of fresh fruits and vegetables in a number of countries in the Region. In addition, the recent interest of consumers in foreign cooking can be an unexpected source of foodborne disease [24].

Increase in susceptible populations

In many developing and industrialized countries, as a result of advances in medical care, the absolute number of elderly people is rapidly increasing as are the number of immunocompromised people. These people have a greater susceptibility to foodborne diseases [25-30].

\section{Conclusion}

In the absence of strong consumer protection bodies, consumer groups and informed citizens aware of food safety and their right to safe food, it remains a significant challenge for many countries in the Eastern Mediterranean Region to respond in the most appropriate way to the needs of their people for safe and healthy food.

The high costs of complying with Codex Alimentarius and other standards recognized by the World Trade Organization, such as the Sanitary and Phytosanitary Agreement and Technical Barriers to Trade, continue to create obstacles to market expansion of Member States (Table 1). Countries have sometimes been able to comply but often the available technical and financial resources have been inadequate. Unless countries allocate sufficient funds for food safety activities, they will be unable to control foodborne diseases and will have difficulty in international trade and tourism.

Today food safety is one of WHO's top 11 priorities and WHO Member States have adopted a strongly worded resolution that recognizes food safety as an essential public health function [6]. The regional action plan for the Eastern Mediterranean to address food safety in the 21 st century was adopted in resolution EM/RC 46/R.6 at the 46th Regional Committee. The integration of research data, food control monitoring, epidemiological investigations and disease surveillance in a renewed effort to manage and lower foodborne risk is urgently needed. The development of an interdisciplinary approach with direct interaction between monitoring, surveillance and risk analysis systems could be a potential basis for improved foodborne disease prevention. Such prevention efforts naturally have to integrate the entire food production chain, from farm to fork, recognizing that the

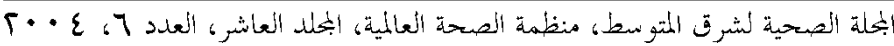


Table 1 Membership in the World Trade Organization and international standard setting bodies of member countries of the WHO Eastern Mediterranean Region (EMR)

\begin{tabular}{|c|c|c|c|c|}
\hline \multirow[t]{2}{*}{ EMR country } & \multicolumn{4}{|c|}{ Membership of } \\
\hline & $\begin{array}{l}\text { World Trade } \\
\text { Organization }\end{array}$ & $\begin{array}{c}\text { Codex } \\
\text { Alimentarius }^{b}\end{array}$ & $\begin{array}{c}\text { World } \\
\text { Organization for } \\
\text { Animal Health }\end{array}$ & $\begin{array}{c}\text { International } \\
\text { Plant Protection } \\
\text { Convention }\end{array}$ \\
\hline Afghanistan & Request submittede & - & $\sqrt{ }$ & - \\
\hline Bahrain & $\sqrt{ }$ & $\sqrt{ }$ & $\sqrt{ }$ & $\sqrt{ }$ \\
\hline Djibouti & $\sqrt{ }$ & - & $\sqrt{ }$ & - \\
\hline Egypt & $\sqrt{ }$ & $\sqrt{ }$ & $\sqrt{ }$ & $\sqrt{ }$ \\
\hline $\begin{array}{l}\text { Islamic Republic } \\
\text { of Irane }\end{array}$ & Request submitted & $\sqrt{ }$ & $\sqrt{ }$ & $\sqrt{ }$ \\
\hline Iraqe & Request submittede & $\sqrt{ }$ & $\sqrt{ }$ & $\sqrt{ }$ \\
\hline Jordan & $\sqrt{ }$ & $\sqrt{ }$ & $\sqrt{ }$ & $\sqrt{ }$ \\
\hline Kuwait & $\sqrt{ }$ & $\sqrt{ }$ & $\sqrt{ }$ & - \\
\hline Lebanon & Applied $^{\dagger}$ & $\sqrt{ }$ & $\sqrt{ }$ & $\sqrt{ }$ \\
\hline $\begin{array}{l}\text { Libyan Arab } \\
\text { Jamahiriya }\end{array}$ & Request submittede & $\sqrt{ }$ & $\sqrt{ }$ & $\sqrt{ }$ \\
\hline Morocco & $\sqrt{ }$ & $\sqrt{ }$ & $\sqrt{ }$ & $\sqrt{ }$ \\
\hline Oman & $\sqrt{ }$ & $\sqrt{ }$ & $\sqrt{ }$ & $\sqrt{ }$ \\
\hline Pakistan & $\sqrt{ }$ & $\sqrt{ }$ & $\sqrt{ }$ & $\sqrt{ }$ \\
\hline Qatar & $\sqrt{ }$ & $\sqrt{ }$ & $\sqrt{ }$ & - \\
\hline Saudi Arabia & Applied ${ }^{\dagger}$ & $\sqrt{ }$ & $\sqrt{ }$ & $\sqrt{ }$ \\
\hline Somalia & - & - & $\sqrt{ }$ & - \\
\hline Sudan & Applied ${ }^{f}$ & $\sqrt{ }$ & $\sqrt{ }$ & $\sqrt{ }$ \\
\hline Syrian Arab Republic & Request submittede & $\sqrt{ }$ & $\sqrt{ }$ & - \\
\hline Tunisia & $\sqrt{ }$ & $\sqrt{ }$ & $\sqrt{ }$ & $\sqrt{ }$ \\
\hline United Arab Emirates & $\sqrt{ }$ & $\sqrt{ }$ & $\sqrt{ }$ & $\sqrt{ }$ \\
\hline Yemen & Applied ${ }^{\dagger}$ & $\sqrt{ }$ & $\sqrt{ }$ & $\sqrt{ }$ \\
\hline Total members & 11 & 18 & 21 & 15 \\
\hline
\end{tabular}

aSource: World Trade Organization: www.wto.org (accessed 13 June 2005).

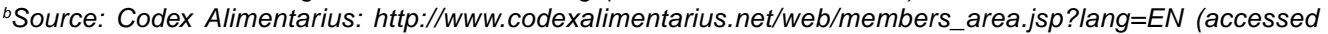
13 June 2005).

'Source: World Organization for Animal Health: http://www.oie.int/eng/OIE/PM/en_PM.htm (accessed 13 June 2005).

${ }^{d}$ Source: International Plant Protection Convention: https://www.ippc.int/IPP/En/default.jsp (accessed 13 June 2005).

${ }^{e}$ Requested accession but working parties on application have not yet met.

IIn the process of negotiation to become members of the World Trade Association. 
critical point for efficient prevention might be at the farm for some problems or at the retail level for others. Most food safety systems currently in place around the world have not been designed according to this important principle. Such lack of coherence and consistency has in some cases undermined the efficiency of food safety systems

There are numerous pressing challenges in the area of food safety and now is the time for change. The recognition of the problems has spurred a new wave of solu- tions. However, these solutions will not be realized without active support from all parts of the food production and consumption chain. There is an urgent need for more systematic and aggressive steps to be taken to significantly reduce the risk of microbiological and chemical foodborne diseases. This need must not be ignored. Tackling the issues of food safety is without doubt one of the major challenges for the 21 st century with regard to the protection of human health.

\section{References}

1. Seward RA. Definition of food safety. In: Schmidt RH, Rodrick GE, eds. Food safety handbook. New Jersey, Hoboken, John Wiley \& Sons Inc., 2003.

2. Food safety: current status and future needs. Washington DC, American Academy of Microbiology, 1999.

3. Assuring food safety and quality: guidelines for strengthening national food control systems. Rome, Food and Agriculture Organization of the United $\mathrm{Na}$ tions and World Health Organization, 2003.

4. Joint FAO/WHO Technical Consultation on Food Safety Regulation and International Trade in the Near East Region. Paper presented at the Twenty-seventh FAO Regional Conference for the Near East, 13-17 March 2004, Doha, Qatar.

5. The present state of foodborne disease in OECD countries. Geneva, World Health Organization, 2003.

6. Global surveillance of foodborne disease: developing a strategy and its interaction with risk analysis. Report of a WHO Consultation, 26-29 November 2001, Geneva, Switzerland. Geneva, World Health Organization, 2002 (WHO/ CDS/CSR/EPH/2002. 21).
7. Ryan MJ et al. Outbreaks of infectious intestinal disease in residential institutions in England and Wales 1992-1994. Journal of infection, 1997, 34:49-54.

8. Methods for foodborne disease surveillance in selected sites. Report of a WHO Consultation 18-21 March 2002, Leipzig, Germany. Geneva, World Health Organization, 2002 (WHO/CDS/ CSR/EPH/2002. 22).

9. WHO Global Strategy for Food Safety: safer food for better health. Geneva, World Health Organization, 2002.

10. Aarestrup FM et al. Resistance to antimicrobial agents used for animal therapy in pathogenic, zoonotic and indicator bacteria isolated from different food animals in Denmark: a baseline study for the Danish Integrated Antimicrobial Resistance Monitoring (DANMP). Acta pathologica microbiologica scandinavica, 1998, 106:745-70.

11. Smith KE et al. Quinolone-resistant Campylobacter jejuni infection in Minnesota, 1992-1998. New England journal of medicine, 1999, 340:1525-32.

12. Angulo F. Emergence of highly mutidrug resistant Salmonella Newport infections. Paper presented at the Euroconference:

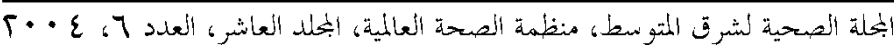


Risk Management Strategies - Monitoring and Surveillance, Dublin, 7-9 September 2002.

13. The increasing incidence of human campylobacteriosis report and proceedings of a WHO consultation of experts, Copenhagen, Denmark, 21-25 November 2000. Geneva, World Health Organization, 2001.

14. Sobel $\mathrm{J}$ et al. Investigation of multistate foodborne disease outbreaks. Public health reports, 2002, 117:8-19.

15. Lee W-C et al. Foodborne illness outbreaks in Korea and Japan studied retrospectively. Journal of food protection, 2001, 64:899-902.

16. Beuchat LR, Ryan JH. Produce handling and processing practices. Emerging infectious diseases, 1997, 3:459-65.

17. Bern $\mathrm{C}$ et al. Epidemiologic studies of Cyclospora cayetanensis in Guatemala. Emerging infectious diseases, 1999, 5(6):766-74.

18. Hodeshi $M$ et al. Massive outbreak of Escherichia coli O157:H7 infection in schoolchildren in Sakai City, Japan, associated with consumption of white radish sprouts. American journal of epidemiology, 1999, 150:787-96.

19. Döller PC et al. Cyclosporiasis outbreak in Germany associated with the consumption of salad. Emerging infectious diseases, 2002, 8:992-4.

20. Rocourt J, Cossart P. Listeria monocytogenes. In: Doyle MP, Beuchat LR, Montville TJ, eds. Food microbiology: fundamentals and frontiers. Washington DC, American Society for Microbiology, 1997:337-52.

21. Travel Industry Association of America. International Visitor Information System: ht t p://www.tia.org/ivis/world tourism.asp\#arrivals (accessed: 13 June 2005.

22. Kaferstein FK, Motarjemi Y, Bettcher DW. Foodborne disease control: a transnational challenge. Emerging infectious diseases, 1997, 3(4):503-10.

23. Steinberg EB et al. Cholera in the United States, 1995-2000: trends at the end of the twentieth century. Journal of infectious diseases, 2001, 184:799-802.

24. Vaillant $\mathrm{V}$ et al. Intoxication alimentaire $\mathrm{a}$ la ciguatera: savoir l'evoquer meme en l'absence de voyage. [Food poisoning from ciguatera: to consider even in the absence of travel.] Bulletin Epidémiologique Hebdomadaire, 2001, 38.

25. Levine WC et al. Foodborne disease outbreaks in nursing homes, 1975 through 1987. Journal of the American Medical Association, 1991, 266:2105-10.

26. Mishu B et al. Outbreaks of Salmonella enteritidis infections in the United States, 1985-1991. Infectious diseases, 1994, 169(3):547-52.

27. Morris JG, Potter ME Jr. Emergence of new pathogens as a function of changes in host susceptibility. Emerging infectious diseases, 1997, 3:435-42.

28. Garly ML et al. Toxoplasmosis in Danish AIDS patients. Scandinavian journal of infectious diseases, 1997, 29:597-600.

29. Gerba CP, Rose JB, Haas CN. Sensitive populations: who is at the greatest risk? International journal of food microbiology, 1996, 30:113-23.

30. Gerber A et al. Clinical course and the role of shiga toxin-producing Escherichia coli infection in the hemolyticuremic syndrome in pediatric patients, 1997-2000, in Germany and Austria: a prospective study. Journal of infectious diseases, 2002, 186:493-500. 